\title{
Variability of organic and elemental carbon, water soluble organic carbon, and isotopes in Hong Kong
}

\author{
K. F. Ho ${ }^{1}$, S. C. Lee ${ }^{1}$, J. J. Cao ${ }^{2}$, Y. S. Li ${ }^{1}$, J. C. Chow ${ }^{3}$, J. G. Watson ${ }^{3}$, and K. Fung ${ }^{4}$ \\ ${ }^{1}$ Research Center for Urban Environmental Technology \& Management, Department of Civil \& Structural Engineering, The \\ Hong Kong Polytechnic University, Hong Kong, China \\ ${ }^{2}$ State Key Laboratory of Loess \& Quaternary Geology, Institute of Earth Environment, Chinese Academy of \\ SciencesInstitute of Earth Environment, China \\ ${ }^{3}$ Division of Atmospheric Sciences, Desert Research Institute, 2215 Raggio, Parkway, P.O. Box 60220, Reno, NV 89506, \\ USA \\ ${ }^{4}$ AtmAA Inc., 23917 Craftsman Road, Calabasas, CA 91302, USA
}

Received: 13 February 2006 - Published in Atmos. Chem. Phys. Discuss.: 9 August 2006

Revised: 12 September 2006 - Accepted: 6 October 2006 - Published: 12 October 2006

\begin{abstract}
To determine the levels and variations of carbonaceous aerosol in Hong Kong, $\mathrm{PM}_{2.5}$ and $\mathrm{PM}_{10}$ samples were collected by high volume (Hi-vol) samplers at three monitoring stations (representing middle-scale roadside, urban-, and regional-scale environments) during winter (November 2000 to February 2001) and summer (June 2001 to August 2001) periods. The highest concentrations of organic carbon (OC), elemental carbon (EC), and water-soluble organic carbon (WSOC) were found at the middle-scale roadside site with the lowest at the regional-scale site. The percentages of WSOC in total carbon at these sites were inversely correlated with their concentrations (i.e., the highest percentages of WSOC were observed at the regional-scale site). A high WSOC fraction may be associated with aged aerosol because of the secondary formation by photochemical oxidation of organic precursors of anthropogenic pollutants during transport. The annual average of isotope abundances $\left(\delta^{13} \mathrm{C}\right)$ of $\mathrm{OC}$ and EC were $-26.9 \pm 0.5 \%$ and $-25.6 \pm 0.1 \%$, respectively. There were no notable differences for seasonal distributions of carbon isotopic composition, consistent with motor vehicle emissions being the main source contributors of carbonaceous aerosol in Hong Kong. $\mathrm{OC}^{13} \mathrm{C}$ abundances at the regional-scale site were higher than those at the middle-scale roadside and urban sites, consistent with secondary organic aerosols of biogenic origin.
\end{abstract}

$\overline{\text { Correspondence to: } \text { S. C. Lee }}$

(ceslee@polyu.edu.hk)

\section{Introduction}

In recent years, much research interest has been focused on atmospheric carbonaceous particles due to their influence on climate and adverse health effects (Chameides, 2002; Frazer, 2002). Total carbonaceous aerosol (TC) comprises a complex mixture that is classified mainly in two fractions: elemental carbon (EC, also called black carbon $[\mathrm{BC}]$ or soot) and organic carbon (OC). EC is emitted directly from combustion sources and undergoes little chemical transformation. It is a good indicator of primary anthropogenic air pollutants. However, OC can be emitted both from primary emission sources and from chemical reactions of gaseous organic precursors in the atmosphere (Turpin and Huntzicker, 1995). Organic compounds such as polycyclic aromatic hydrocarbon (PAH), oxy-PAH, and nitro-PAH are potential mutagens or carcinogens that have been found in urban particulate matter (PM). In most urban areas, OC and EC constitute $\sim 20$ to $50 \%$ of fine particle $\left(\mathrm{PM}_{2.5}\right.$, particles with aerodynamic diameter less than $2.5 \mu \mathrm{m}$ ) mass (Chow et al., 1993).

Urban air pollution in Asia has been increasing and has become recognized at the regional, continental, and global scales (Street et al., 1999). Menon et al. (2002) showed that $\mathrm{BC}$ emitted from China and India affects regional climates. Cooke et al. (1999) estimated that $\sim 25 \%$ of global anthropogenic $\mathrm{BC}$ emissions originate from China. In contrast to other pollutants such as sulfate and nitrate, observations of $\mathrm{OC}$ and EC in Asia are insufficient (Cheng et al., 2000; Ho et al., 2003; Yao et al., 2002) for quantitative assessment of their environmental and climatic effects.

Hong Kong, located on the southeastern coast of the Asiatic mainland and on the southern tip of the highly economically developed Pearl River Delta (PRD) region in China,

Published by Copernicus GmbH on behalf of the European Geosciences Union. 
Table 1. Description of the three monitoring sites in Hong Kong.

\begin{tabular}{|c|c|c|c|}
\hline Site name (Code) Zone of representation & Site type & Site elevation & Site description \\
\hline PolyU (PU) & roadside & $\sim 6 \mathrm{~m}$ a.s.1. & $8 \mathrm{~m}$ from a heavily-trafficked roadway that leads to the Cross \\
\hline Roadside & & & Harbour Tunnel. Traffic volume 170000 vehicles per day. \\
\hline Kwun Tong (KT) Urban & $\begin{array}{l}\text { urban- } \\
\text { residential }\end{array}$ & $\sim 25 \mathrm{~m}$ a.s.1. & Near residential buildings with lightly-trafficked streets. \\
\hline $\begin{array}{l}\text { Hok Tsui (HT) } \\
\text { Backgroud }\end{array}$ & $\begin{array}{l}\text { regional } \\
\text { boundary }\end{array}$ & $60 \mathrm{~m}$ a.s.1. & $\begin{array}{l}\text { Near the coast at } 60 \mathrm{~m} \text { above sea level with } 240^{\circ} \text { of ocean view from } \\
\text { northeast to southwest. } 10 \mathrm{~km} \text { away from urban areas and major roads. }\end{array}$ \\
\hline
\end{tabular}

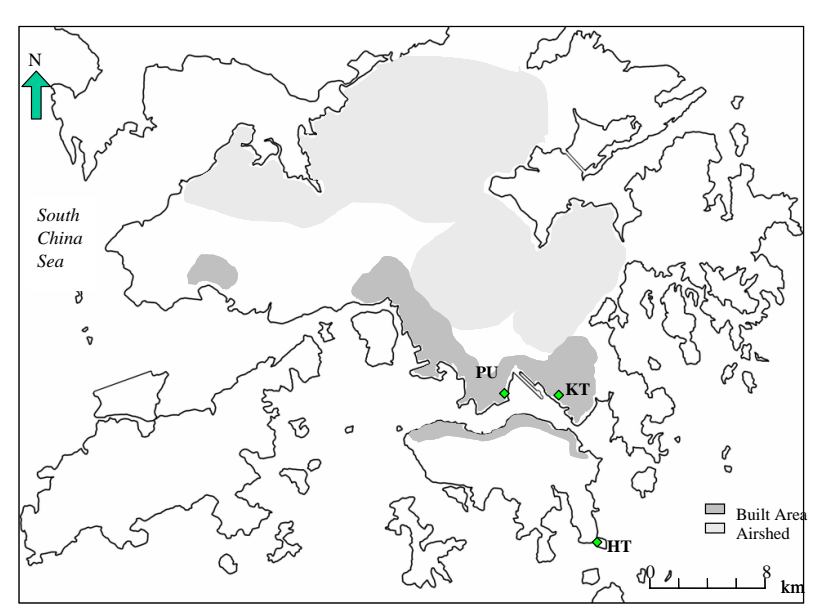

Fig. 1. Location of monitoring sites: middle-scale roadside Hung Hom (Hong Kong Polytechnic University Campus [PU]); urbanscale Kwun Tong (KT); and regional-scale Hok Tsui (HT) in Hong Kong.

is one of the most densely populated metropolitan areas in Asia. Most of Hong Kong's 7 million inhabitants reside on $\sim 15 \%$ of its $1068 \mathrm{~km}^{2}$ land area. According to The Census and Statistics Department of Hong Kong, 517000 registered vehicles traveled on $1904 \mathrm{~km}$ of roads in 2000. Diesel trucks with high EC emissions accounted for $\sim 30 \%$ of the vehicle fleet. Air pollution in Hong Kong is also influenced by heavy industry, agricultural production, and shipping in the PRD region.

Ambient monitoring of $\mathrm{PM}_{2.5}$ and $\mathrm{PM}_{10}$ (particles with aerodynamic diameter less than $10 \mu \mathrm{m})$ and $\mathrm{PM}_{2.5}$ mass and carbon was conducted during winter (November 2000 to February 2001) and summer (June to August 2001) at three sites in Hong Kong. In addition to OC and EC, water-soluble organic carbon (WSOC) and ${ }^{13} \mathrm{C}$ abundances in $\mathrm{OC}$ and $\mathrm{EC}$ were measured to understand their characteristics in the region. This paper examines the spatial and seasonal variations of OC, EC, WSOC, and carbon isotopes.

\section{Methodology}

\subsection{Sampling sites}

The three sampling sites shown in Fig. 1 include: a vehicle emission dominated middle-scale roadside Hung Hom site (Polytechnic University campus, PU); an urbanscale commercial-residential Kwun Tong (KT) site; and the regional-scale Hok Tsui (HT) site. Detailed site descriptions are given in Table 1 .

\subsection{Particulate matter collection}

Twenty-four-hour sampling (midnight to midnight) was carried out every sixth day at the PU and KT sites, and five $\mathrm{PM}_{2.5}$ and $\mathrm{PM}_{10}$ samples each were collected during winter and summer seasons at HT. PMsamples were acquired on $20.3 \mathrm{~cm} \times 25.4 \mathrm{~cm}$ Whatman quartz microfibre filters $(\mathrm{QM} / \mathrm{A}$, Whatman Inc., Clifton, NJ, USA) by high volume (hi-vol) samplers (Graseby-Andersen, Atlanta, GA, USA) operated at flow rates of 1130 to $1410 \mathrm{~L} / \mathrm{min}$. Two Partisol model 2000 (Rupprecht and Patashnick, Albany, NY) low volume samplers with 10 and $2.5 \mu \mathrm{m}$ inlets, operated at $16.7 \mathrm{~L} / \mathrm{min}$, was used to collect $\mathrm{PM}_{2.5}$ and $\mathrm{PM}_{10}$ mass on Teflon-membrane filters (Pall Life Sciences, Ann Arbor, MI). The difference between the hi-volume and the Partisol 2000 samplers was less than $7 \%$ for $\mathrm{PM}_{2.5}$ and $\mathrm{PM}_{10}$ mass. The quartz-fiber filters were baked before sampling at $900^{\circ} \mathrm{C}$ for $3 \mathrm{~h}$ to remove organic artifacts or impurities. After sampling, samples were stored in a refrigerator at $\sim 4^{\circ} \mathrm{C}$ prior to chemical analysis to prevent the loss of volatile components. Approximately $5 \%$ of field blanks were collected to subtract the positive artifacts that resulted from adsorption of gas-phase organic compounds onto the filter during and/or after sampling. Negative artifacts due to the volatilization of particle-phase organics from particle samples were not quantified in this study.

\subsection{OC, EC, and WSOC analyses}

Winter samples were analyzed for OC and EC by selective thermal manganese dioxide oxidation (TMO) with a modified Dohrmann DC-52 carbon analyzer (Fung and Wright, 1990) at AtmAA Inc. of Calabasas, CA, USA. Summer samples were analyzed using a DRI Model 2001 Thermal/Optical 
Carbon Analyzer (Atmoslytic Inc., Calabasas, CA) at the Hong Kong Polytechnic University following the Interagency Monitoring of PROtected Visual Environments (IMPROVE) thermal/optical reflectance (TOR) protocol (Chow et al., 1993). Previous laboratory comparisons between TMO and TOR by Fung et al. (2002) showed comparability for TC (total carbon), OC, and EC. Inter-laboratory comparison between the two methods during this study reported $<5 \%$ difference for TC and $\sim 10 \%$ differences for OC and EC. OC and EC data can be compared with minimal analytical bias.

Several methods have been used to analyze WSOC in particulate samples by using the water extract of a filter sample (Yang et al., 2003). For this study, five punches $\left(0.526 \mathrm{~cm}^{2}\right)$ were removed from a filter and placed into a flat-bottomed screw-capped vial to which $1 \mathrm{ml}$ of distilled de-ionized water (DDW) was added. Sample vials were heated in an oven at $\sim 95^{\circ} \mathrm{C}$ for $\sim 0.5 \mathrm{~h}$. Samples were cooled to room temperature and stood for $\sim 48 \mathrm{~h}$. About $0.5 \mathrm{ml}$ of the filter extract was transferred to another vial by syringe and $20 \mu \mathrm{l}$ were taken for WSOC analysis. Triplicate analyses showed that a precision of $\pm 10 \%$ can be achieved.

\subsection{Stable carbon isotope analyses}

Stable isotope analysis $\left({ }^{13} \mathrm{C} /{ }^{12} \mathrm{C}\right)$ of TC differs by emission source (Chesselet et al., 1981; Cachier et al., 1986, 1989; Martinelli et al., 2002). Only limited studies have examined isotope abundance $\left(\delta^{13} \mathrm{C}\right)$ in atmospheric OC and EC (Szidat et al., 2004; Huang et al., 2006). Variations of $\delta^{13} \mathrm{C}$ in OC and $\mathrm{EC}$ may provide a better understanding of the source and fate of carbonaceous aerosol.

OC and EC are operationally defined. Watson et al. (2004) describes more than 20 international thermal combustion carbon methods for OC and EC. Different methods compound the uncertainties while evaluating isotope abundances in OC and EC (Reddy et al., 2002; Szidat et al., 2004; Huang et al., 2006).

In the study, $\delta^{13} \mathrm{C}$ was determined from carbon dioxide $\left(\mathrm{CO}_{2}\right)$ evolving at two temperatures and detected with a Finnigan MAT-251 mass spectrometer (Thermo Electron Corporation, Burlington, Ontario, Canada). Particulate carbonate was removed with hydrochloric acid prior to isotopic analysis. The remaining carbon was oxidized to $\mathrm{CO}_{2}$ with $\mathrm{CuO}$ catalyst grains by heating at $375^{\circ} \mathrm{C}$ (no oxygen $\left[\mathrm{O}_{2}\right]$ under vacuum) for $3 \mathrm{~h}$. The $\mathrm{CO}_{2}$ was isolated through a series of cold traps and $\delta^{13} \mathrm{C}$ in OC was quantified by offline analysis with a Finnigan MAT-251 mass spectrometer. The filter was then combusted at $850^{\circ} \mathrm{C}$ for $5 \mathrm{~h}$, and the resulting $\mathrm{CO}_{2}$ was purified in cold traps to determine $\delta^{13} \mathrm{C}$ in EC. $\delta^{13} \mathrm{C}$ international standard (PDB) as:

$\delta^{13} \mathrm{C}=\left({ }^{13} \mathrm{C} /{ }^{12} \mathrm{C}_{\text {sample }} /{ }^{13} \mathrm{C} /{ }^{12} \mathrm{C}_{\text {standard }}-1\right) \times 1000$

Samples (five replicate analyses) were analyzed at least in duplicate with a maximum allowable difference of $0.3 \%$.

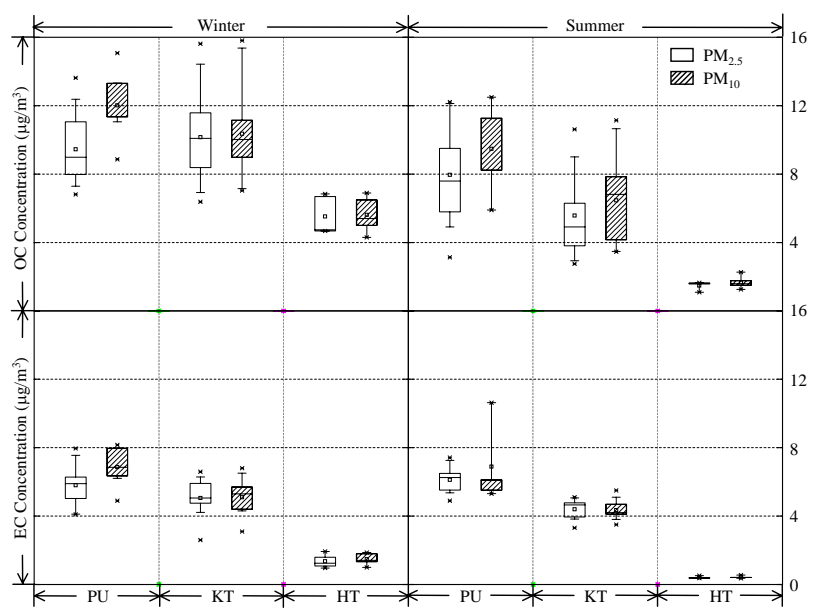

Fig. 2. Box plots of organic carbon (OC) and elemental carbon (EC) concentrations $\left(\mu \mathrm{g} / \mathrm{m}^{3}\right)$ in $\mathrm{PM}_{2.5}$ and $\mathrm{PM}_{10}$ samples during the winter and summer periods at middle-scale roadside Hung Hom (Hong Kong Polytechnic University Campus [PU]); urbanscale Kwun Tong (KT); and regional-scale Hok Tsui (HT) in Hong Kong.

\section{Meteorological conditions}

The climate in Hong Kong $(22.12 \mathrm{~N}, 114.08 \mathrm{E})$ is subtropical, under the influence of the Asian monsoon. Summer and winter are the two longest seasons, each with distinct meteorological characteristics. Prevailing southwesterly wind during summer brings warm and damp air masses from the South China Sea. In winter, prevailing northeasterly wind travels across South China before reaching Hong Kong. Air quality in Hong Kong is poorest in winter due to the influence of local sources and polluted air mass transported from South China. The meteorological information in this study was obtained from Hong Kong Observatory (HKO).

\section{Results and discussion}

\subsection{Spatial and seasonal distributions of OC and EC}

A total of $100 \mathrm{PM}_{2.5}$ and $\mathrm{PM}_{10}$ samples (including field blanks) were collected for this study. Spatial and seasonal distributions of OC and EC are illustrated in Fig. 2, with average concentrations listed in Table 2. $\mathrm{PM}_{2.5}$ mass varied from $10-39 \mu \mathrm{g} \mathrm{m}^{-3}$ during summer and from $42-53 \mu \mathrm{g} \mathrm{m}^{-3}$ during winter. Corresponding $\mathrm{PM}_{10}$ concentrations were 15 $54 \mu \mathrm{g} \mathrm{m}^{-3}$ during summer and $76-83 \mu \mathrm{g} \mathrm{m}^{-3}$ during winter. $\mathrm{PM}_{2.5}$ accounted for $72-76 \%$ of $\mathrm{PM}_{10}$ mass during summer, compared to $53-81 \%$ during winter. On average, TC (i.e., $\mathrm{OC}+\mathrm{EC}$ ) explains $26 \%$ and $32 \%$ of $\mathrm{PM}_{2.5}$ mass during winter and summer, respectively. The corresponding TC fractions were $6-7 \%$ less in $\mathrm{PM}_{10}$. The average $\mathrm{TC}$ in $\mathrm{PM}_{2.5}$ and $\mathrm{PM}_{10}$ was $25.5 \pm 8.3 \%$ and $18.4 \pm 7.0 \%$, respectively, in 
Table 2. Average ( \pm std. deviation) $\mathrm{PM}_{2.5}$ and $\mathrm{PM}_{10}$ organic carbon $(\mathrm{OC})$ and elemental carbon (EC) concentrations during the winter and summer at three monitoring sites.

\begin{tabular}{|c|c|c|c|c|c|c|c|c|c|c|c|c|}
\hline & & $\begin{array}{l}\text { No. of } \\
\text { samples }\end{array}$ & & & $\mathrm{PM}_{2.5}$ & & & & & & $\mathrm{PM}_{10}$ & \\
\hline & & & Mass & $\mathrm{OC}$ & $\mathrm{EC}$ & \multirow{2}{*}{ TC/Mass (\%) } & \multirow{2}{*}{ OC/EC } & Mass & $\mathrm{OC}$ & $\mathrm{EC}$ & \multirow{2}{*}{ TC/Mass $(\%)$} & \multirow{2}{*}{$\mathrm{OC} / \mathrm{EC}$} \\
\hline & & & & $\mu \mathrm{g} \mathrm{m}^{-3}$ & & & & & $\mu \mathrm{g} \mathrm{m}^{-3}$ & & & \\
\hline \multirow[t]{2}{*}{ PU (urban) } & Winter & 26 & $52.5 \pm 5.4$ & $11.2 \pm 1.8$ & $6.4 \pm 1.2$ & $33.3 \pm 3.2$ & 1.8 & $83.0 \pm 18.4$ & $12.1 \pm 2.2$ & $7.0 \pm 1.2$ & $23.5 \pm 3.3$ & 1.7 \\
\hline & Summer & 10 & $39.0 \pm 9.1$ & $10.2 \pm 2.4$ & $5.9 \pm 0.3$ & $41.9 \pm 4.2$ & 1.7 & $53.5 \pm 12.5$ & $11.1 \pm 2.2$ & $6.3 \pm 0.3$ & $33.3 \pm 4.1$ & 1.8 \\
\hline \multirow{2}{*}{$\begin{array}{l}\text { KT (urban- } \\
\text { residential) }\end{array}$} & Winter & 22 & $61.7 \pm 32.0$ & $8.8 \pm 1.8$ & $4.8 \pm 0.6$ & $24.8 \pm 7.1$ & 1.8 & $76.3 \pm 30.2$ & $9.5 \pm 1.9$ & $5.1 \pm 0.6$ & $20.6 \pm 5.4$ & 1.8 \\
\hline & Summer & 22 & $30.1 \pm 10.6$ & $5.9 \pm 2.5$ & $4.5 \pm 0.6$ & $37.1 \pm 3.6$ & 1.6 & $39.8 \pm 11.5$ & $6.9 \pm 2.5$ & $4.8 \pm 0.6$ & $27.3 \pm 8.4$ & 1.6 \\
\hline \multirow{2}{*}{$\begin{array}{l}\text { HT (urban } \\
\text { background) }\end{array}$} & Winter & 10 & $42.4 \pm 13.3$ & $5.5 \pm 1.1$ & $1.4 \pm 0.4$ & $16.9 \pm 3.1$ & 4.1 & $80.0 \pm 30.4$ & $5.9 \pm 1.1$ & $1.6 \pm 0.4$ & $9.9 \pm 2.1$ & 3.8 \\
\hline & Summer & 10 & $10.5 \pm 1.8$ & $1.5 \pm 0.3$ & $0.4 \pm 0.1$ & $18.3 \pm 2.2$ & 3.6 & $14.5 \pm 2.8$ & $1.9 \pm 0.4$ & $0.5 \pm 0.1$ & $16.7 \pm 5.3$ & 4.3 \\
\hline \multirow[t]{2}{*}{ Average } & Winter & 58 & $52.2 \pm 19.8$ & $8.7 \pm 2.8$ & $4.3 \pm 2.3$ & $25.5 \pm 8.3$ & 2.5 & $80.0 \pm 24.7$ & $9.3 \pm 3.2$ & $4.7 \pm 2.5$ & $18.4 \pm 7.0$ & 2.4 \\
\hline & Summer & 42 & $27.4 \pm 13.6$ & $5.9 \pm 3.8$ & $3.6 \pm 2.1$ & $32.4 \pm 11.1$ & 2.3 & $36.9 \pm 17.5$ & $6.7 \pm 3.9$ & $3.8 \pm 2.3$ & $26.1 \pm 9.0$ & 2.3 \\
\hline
\end{tabular}

Table 3. Average ( \pm std. deviation) $\mathrm{PM}_{2.5}$ and $\mathrm{PM}_{10}$ water-soluble organic carbon (WSOC) concentrations during winter and summer at three monitoring sites.

\begin{tabular}{|c|c|c|c|c|c|c|c|c|c|c|}
\hline & & \multirow[t]{2}{*}{ No. of samples } & \multicolumn{3}{|c|}{$\mathrm{PM}_{2.5}$} & \multicolumn{4}{|c|}{$\mathrm{PM}_{10}$} & \multirow[b]{2}{*}{ WSOC/EC } \\
\hline & & & $\begin{array}{l}\text { WSOC } \\
\mu \mathrm{g} \mathrm{m}^{-3}\end{array}$ & $\begin{array}{l}\text { WSOC/OC } \\
(\%)\end{array}$ & $\begin{array}{l}\text { WSOC/Mass } \\
(\%)\end{array}$ & WSOC/EC & $\begin{array}{l}\text { WSOC } \\
\mu \mathrm{g} \mathrm{m}^{-3}\end{array}$ & $\begin{array}{l}\text { WSOC/OC } \\
(\%)\end{array}$ & $\begin{array}{l}\text { WSOC/Mass } \\
(\%)\end{array}$ & \\
\hline \multirow[t]{2}{*}{ PU (urban) } & Winter & 10 & $3.5 \pm 0.5$ & $31.6 \pm 5.5$ & $6.6 \pm 0.7$ & 0.5 & $3.9 \pm 0.6$ & $32.8 \pm 6.2$ & $4.8 \pm 0.8$ & 0.6 \\
\hline & Summer & 10 & $2.1 \pm 0.3$ & $21.5 \pm 6.3$ & $5.6 \pm 1.5$ & 0.4 & $2.4 \pm 0.2$ & $22.6 \pm 6.5$ & $4.7 \pm 1.3$ & 0.4 \\
\hline \multirow[t]{2}{*}{ KT (urban-residential) } & Winter & 10 & $3.4 \pm 1.0$ & $38.4 \pm 7.2$ & $6.1 \pm 2.2$ & 0.7 & $3.7 \pm 1.1$ & $39.3 \pm 7.4$ & $5.3 \pm 2.2$ & 0.7 \\
\hline & Summer & 10 & $2.1 \pm 0.9$ & $34.5 \pm 10.7$ & $8.1 \pm 2.8$ & 0.5 & $2.3 \pm 0.9$ & $32.7 \pm 7.6$ & $6.8 \pm 2.6$ & 0.5 \\
\hline \multirow[t]{2}{*}{ HT (urban background) } & Winter & 10 & $2.8 \pm 0.6$ & $51.3 \pm 7.4$ & $7.1 \pm 2.2$ & 2.0 & $3.1 \pm 0.7$ & $53.1 \pm 5.7$ & $4.1 \pm 1.0$ & 1.9 \\
\hline & Summer & 10 & $1.0 \pm 0.3$ & $69.0 \pm 8.5$ & $9.9 \pm 2.1$ & 2.5 & $1.2 \pm 0.3$ & $62.6 \pm 7.7$ & $8.7 \pm .5$ & 2.4 \\
\hline \multirow[t]{2}{*}{ Average } & Winter & 30 & $3.2 \pm 0.7$ & $39.9 \pm 10.5$ & $6.6 \pm 1.7$ & 0.7 & $3.6 \pm 0.8$ & $41.2 \pm 10.6$ & $4.8 \pm 1.4$ & 0.8 \\
\hline & Summer & 30 & $1.7 \pm 0.7$ & $42.3 \pm 23.1$ & $7.8 \pm 2.7$ & 0.5 & $1.9 \pm 0.8$ & $31.4 \pm 24.1$ & $5.3 \pm 3.8$ & 0.5 \\
\hline
\end{tabular}

winter, which is similar to previous observations by Cao et al. (2003). $\mathrm{PM}_{2.5}$ and $\mathrm{PM}_{10}$ OC concentrations at the PU and $\mathrm{KT}$ sites ranged from 8.8 to $12.1 \mu \mathrm{g} \mathrm{m}^{-3}$ during winter and from 5.9 to $11.1 \mu \mathrm{g} \mathrm{m}^{-3}$ during summer, whereas the corresponding $\mathrm{PM}_{2.5}$ and $\mathrm{PM}_{10} \mathrm{EC}$ ranged from 4.8 to $7.0 \mu \mathrm{g} \mathrm{m}^{-3}$ during winter and 4.5 to $6.3 \mu \mathrm{g} \mathrm{m}^{-3}$ during summer. The seasonal contrast is only $35-55 \%$ for OC and $6-$ $26 \%$ for $\mathrm{EC}$ at the PU and KT sites. Winter $\mathrm{PM}_{2.5}$ and $\mathrm{PM}_{10}$ OC concentrations were 3- to 4-fold and EC concentrations were 3 -fold higher than those found during summer at the HT site.

Several factors can affect the carbon concentrations. Dilution due to increased mixing depths (greater convective mixing) (Sequeira and Lai, 1998) and particle washout on rainy days resulted in lower PM and carbon levels in the summer (monthly average rainfall ranged from 318.9 to $1083 \mathrm{~mm}$ in summer and from 10.9 to $96.8 \mathrm{~mm}$ during winter). Wintertime stagnation decreased the dispersion and transport of pollutants and resulted in an increase in pollution levels. Northeasterly winds during winter carried air pollutants from China to Hong Kong, which elevated PM and carbon concentrations at the regional-scale site.

At the three sites, 78-99\% of EC and 79-98\% of OC in $\mathrm{PM}_{10}$ were found in the $\mathrm{PM}_{2.5}$ fraction of $\mathrm{PM}_{10}$. Average
$\mathrm{PM}_{2.5}$ and $\mathrm{PM}_{10} \mathrm{OC}$ concentrations at the $\mathrm{PU}$ and $\mathrm{KT}$ sites were 2-3 times higher and EC concentrations were 4-5 times higher than those at the HT site. Elevated OC and EC concentrations at the urban sites reflect the influence of vehicle exhaust, along with emissions from restaurants and nearby industries.

Ratios of OC to EC have been used to imply the origin of carbonaceous particles (Turpin et al., 1995; Chow et al., 1993). Table 2 shows that the OC/EC ratios at the two urban sites (1.6-1.8) were half of those found at the regional-scale site, with little variation between summer and winter. Low OC/EC ratios are primarily due to the elevated EC concentrations at the urban sites, implying direct emissions from anthropogenic sources. Elevated OC/EC ratios at the regionalscale site suggested the transport of aged aerosol that may have included secondary organic aerosol (SOA).

\subsection{Variability of WSOC}

The water-soluble fraction of OC (i.e., WSOC) often consists of $>30 \%$ of $\mathrm{PM}_{2.5}$ or $\mathrm{PM}_{10}$ OC, often being associated with polar compounds and correlated with SOA formation (Grosjean et al., 1978; Rogge et al., 1993). WSOC has the potential to modify the hygroscopic properties of particles, 


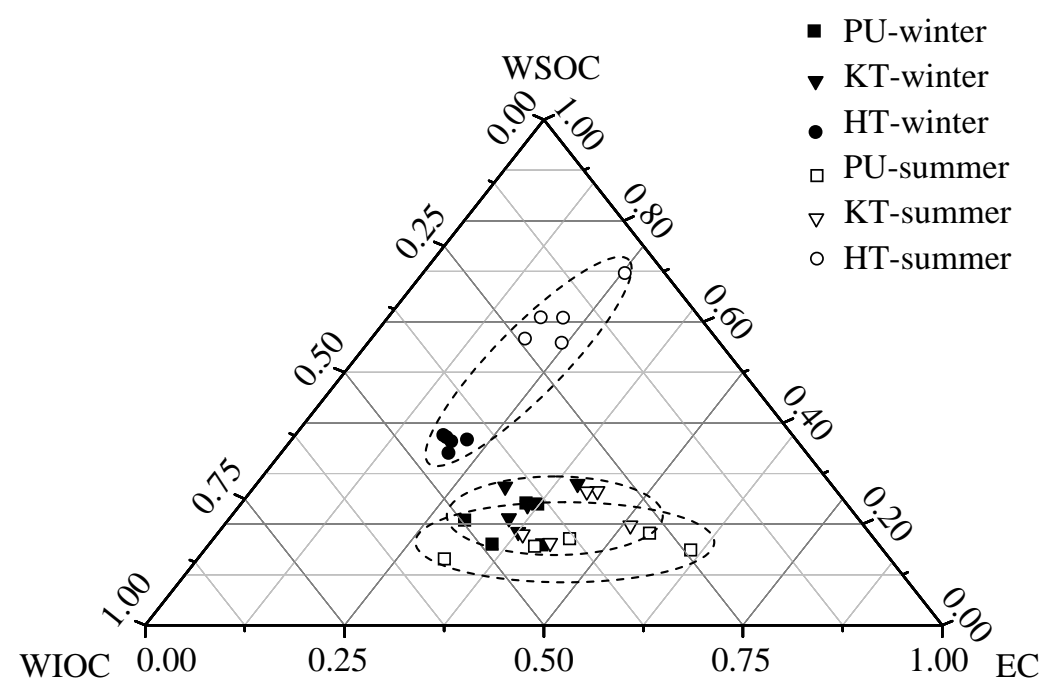

Fig. 3. Compositions of elemental carbon (EC), water-soluble organic carbon (WSOC), and water-insoluble organic carbon (WIOC) (given as fractions of TC) in $\mathrm{PM}_{2.5}$ during the winter and summer periods at middle-scale roadside Hung Hom (Hong Kong Polytechnic University Campus [PU]); urban-scale Kwun Tong (KT); and regional-scale Hok Tsui (HT) in Hong Kong.

including PM size and cloud condensation nuclei activities (Shulman et al., 1996).

A total of 60 samples comprising of five pairs of $\mathrm{PM}_{2.5}$ and $\mathrm{PM}_{10}$ samples selected at each site from the summer and winter seasons were analyzed for WSOC. As shown in Table 3, 80-90\% of the $\mathrm{PM}_{10}$ WSOC was in the $\mathrm{PM}_{2.5}$ fraction, ranging from $1-2 \mu \mathrm{g} \mathrm{m}^{-3}$ during summer and 3$4 \mu \mathrm{g} \mathrm{m}^{-3}$ during winter. Wintertime WSOC was $\sim 1.5-2$ times higher than in summer with less spatial variation. Low summertime WSOC $\left(\sim 1 \mu \mathrm{g} \mathrm{m}^{-3}\right)$ may be due to clean marine air masses from the South China Sea. The major sources of WSOC include primary emissions from biomass burning and cooking, as well as secondary organic aerosol (Chebbi and Carlier, 1996). Transformation and transport of pollutants from urban areas may be the reason for higher $\left(\sim 3 \mu \mathrm{g} \mathrm{m}^{-3}\right)$ wintertime WSOC at the HT site. During the same monitoring period, atmospheric aromatic hydrocarbons such as toluene and xylenes, some of the main precursors of SOA (Ho et al., 2004), were determined. Concentrations of aromatic compounds were 2-6 times higher in winter than in summer at the HT site. The formation of SOA occurs both with the oxidation of naturally emitted terpenes and with anthropogenic volatile organic compounds (VOCs), particularly those with high molecular weights. As VOCs or primary organic aerosols react with photochemically derived oxidants $\left(\mathrm{O}_{3}, \mathrm{OH} \cdot \mathrm{NO}_{3} \cdot\right)$, they generate more polar compounds such as alcohols, carbonyls, carboxylic acids and more complex oxidized compounds (Saxena and Hildemann, 1996). Consequently, it is speculated that a high WSOC fraction is indicative of aged aerosol (e.g. due to photochemical reactions.). This is consistent with the results from Temesi et al. (2003). In addition, previous study has shown that di- carboxylic acids are one of the major identified components of WSOC (Grosjean et al., 1978; Rogge et al., 1993). The spatial-temporal distributions of $\mathrm{PM}_{2.5}$ dicarboxylic acids at the three sites reported by Yao et al. (2004) showed similar trends as WSOC in this study.

The relative percentages of $\mathrm{PM}_{2.5}$ WSOC, water-insoluble OC $(\mathrm{WIOC}=\mathrm{OC}-\mathrm{WSOC})$, and EC in TC are presented in the ternary diagrams (Fig. 3). The percentages of WSOC in TC were similar at PU (13-20\%) and KT (21-24\%) in winter and summer as the smallest fraction of $\mathrm{PM}_{2.5}$ carbon. In contrast, the regional HT site showed that WSOC was the largest TC fraction (41-54\%), with higher summer levels. This is consistent with the notion that regional-scale sites are mostly impacted by aged aerosol. Salma et al. (2001) showed that the mass fraction of WSOC increased from a tunnel to a background area. Meanwhile, the EC concentration is reduced during transport to the background site because of dilution. This explains why WSOC becomes a large fraction (50-70\%) of OC at the HT site and accounts for only about one-third of OC at the PU and KT sites for $\mathrm{PM}_{2.5}$ and $\mathrm{PM}_{10}$ in both seasons. WSOC constitutes small fractions of $\mathrm{PM}_{2.5}$ and $\mathrm{PM}_{10}$ mass, ranging from 5.6 $\pm 1.3 \%$ to $9.9 \pm 2.1 \%$ for $\mathrm{PM}_{2.5}$ and from $4.1 \pm 1.0 \%$ to $8.7 \pm 0.5 \%$ for $\mathrm{PM}_{10}$ (Table 3). The WSOC/OC ratios were higher in winter than in summer at PU and KT. Other than primary emissions, transport from the urban area was one of the possible sources of WSOC in winter. However, the WSOC/OC ratios at the regional-scale HT site were higher in summer $(69 \%)$ than in winter $(51 \%)$. This was the result of more aged aerosols at the HT site. Moreover, elevated WSOC/EC ratios can be used as indicators for aged aerosol. The average WSOC/EC ratios at the urban PU and KT sites were 0.4-0.6 and 0.5- 


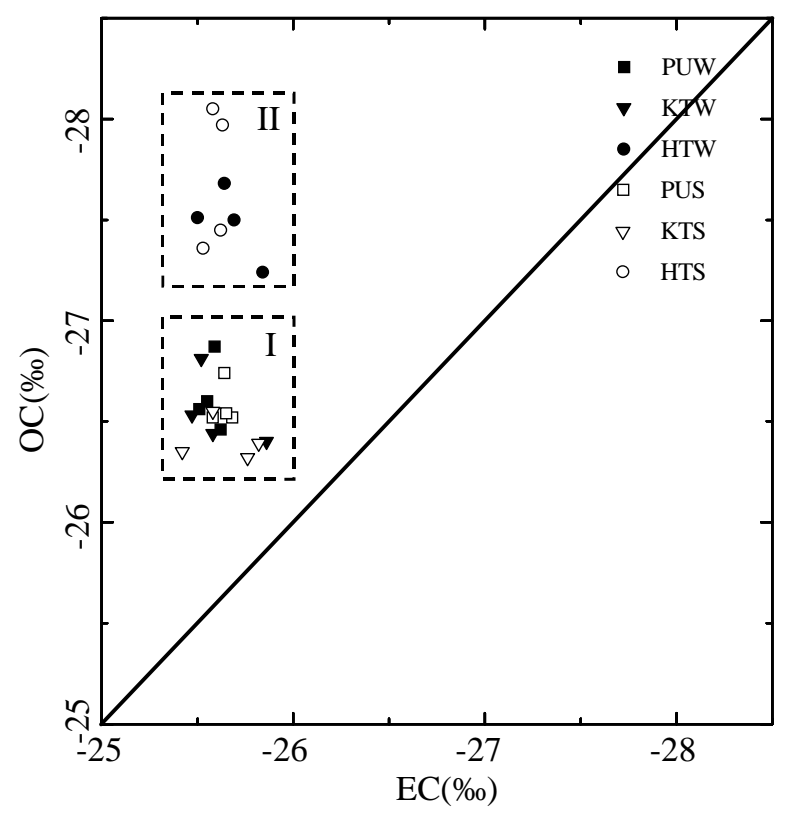

Fig. 4. Isotopic composition $\left(\delta^{13} \mathrm{C}\right)$ of organic carbon $(\mathrm{OC})$ and elemental carbon (EC) during the winter and summer periods at middle-scale roadside Hung Hom (Hong Kong Polytechnic University Campus [PU]); urban-scale Kwun Tong (KT); and regionalscale Hok Tsui (HT) in Hong Kong.

0.7 (Table 3), respectively, which are similar to the ratio at a high-traffic roadside site in Paris (0.32) (Ruellan and Cachier, 2000). However, the average WSOC/EC ratios at the HT site were $\sim 2.0$ for winter and $\sim 2.5$ for summer.

\subsection{Stable carbon isotopic composition of OC and EC}

Twenty-four $\mathrm{PM}_{2.5}$ were analyzed for $\delta^{13} \mathrm{C}$ composition of $\mathrm{OC}$ and of EC, with the results in Fig. 4.

The average $\delta^{13} \mathrm{C}(\mathrm{OC})$ abundance was $-26.9 \pm 0.6 \%$, ranging from $-26.4 \%$ to $-27.7 \%$ during winter. A similar average $\delta^{13} \mathrm{C}(\mathrm{OC})$ abundance $(-26.9 \pm 0.5 \%$ ) was found in summer, ranging from -26.3 to $-28.1 \%$. The average $\delta^{13} \mathrm{C}(\mathrm{EC})$ abundance for both seasons was $-25.6 \pm 0.1 \%$ o ranging from $-25.4 \%$ o to $-25.9 \%$. The small difference in carbon isotopic abundance between the two seasons in Hong Kong is consistent with similar source mixtures. Rudolph et al. (2002) also observed little variability in ${ }^{13} \mathrm{C}$ abundances for nonmethane hydrocarbons (NMHC) from traffic-related sources in the metropolitan region of Toronto. As shown in Fig. $4, \delta^{13} \mathrm{C}$ exhibited isotopic variability among the three sites, and these samples can be grouped into two clusters. Given that the ${ }^{13} \mathrm{C}$ isotopic fractionation between an aerosol and its fuel is small (Turekian et al., 1998; Currie et al., 1999) and that no apparent isotopic fractionation is occurring during particle production and transport (Cachier et al., 1985), similar isotopic composition of OC and EC at the PU and KT sites (Group I in Fig. 4) are consistent with motor vehicle ex- haust as the major contributor. Huang et al. (2006) observed the similar phenomenon of the distribution of $\delta^{13} \mathrm{C}$ in OC and EC from a tunnel site (Cassier Tunnel) and a forest site (Golden Ears) in Canada when motor vehicle exhaust was the dominant sources of two sites. The $\delta^{13} \mathrm{C}(\mathrm{EC})$ at HT is similar to that found at the PU and KT sites, but the $\delta^{13} \mathrm{C}(\mathrm{OC})$ at HT (Group II in Fig. 4) is isotopically lighter than those at the PU and KT sites. $\delta^{13} \mathrm{C}(\mathrm{EC})$ values at the HT site were similar to those at the urban PU and KT sites, suggesting that the majority of the EC originated from motor vehicle emissions. Huang et al. (2006) also found that EC is inert and likely to preserve the primary source characteristics. While $\delta^{13} \mathrm{C}(\mathrm{OC})$ was similar at the PU and KT sites, its abundance was lower at the HT site $(-27.2 \%$ o to $-28.1 \%$ o), implying contributions from non-motor vehicle sources. Cachier et al. (1996) reported that the $\delta^{13} \mathrm{C}(\mathrm{OC})$ associated with sea-salt droplets is $-21 \pm 2$. From the $\delta^{13} \mathrm{C}(\mathrm{OC})$ difference between the HT and PU sites (Fig. 4), it is unlikely that OC at HT is of direct marine origin. The carbon isotopic signatures of $\mathrm{C}_{3}$ in bulk plant materials range from $-27.7 \%$ o to $-29.2 \%$ o (Ballentine et al., 1998). Hence, it may be that biogenic sources, through gas-to-particle conversion processes, contribute to regional OC. The distribution of dicarboxylic acids at the HT site is also consistent with biogenic origins (Yao et al., 2004). Kim et al. (2000) showed that local biogenic emissions of OC might be significant during summer at the Kosan $\left(126^{\circ} 10^{\prime} \mathrm{E}, 33^{\circ} 17^{\prime} \mathrm{N}\right)$ background site in Korea. Szidat et al. (2004) demonstrated that SOA may be formed nearly exclusively from biogenic precursor gases even in an urban environment.

\section{Summary and conclusion}

During the study, average OC concentrations in $\mathrm{PM}_{2.5}$ and $\mathrm{PM}_{10}$ fractions at the urban sites were higher in winter than in summer. The highest concentration of EC was observed at the micro-scale roadside PU site in both seasons because of the nearby vehicle emissions. Relatively low OC and EC concentrations were found at the HT regional-scale site because it was far from direct emission sources. OC/EC ratios at HT were larger than those at the PU and KT sites owing to the formation of SOA during transport. Average $\mathrm{PM}_{2.5}$ and $\mathrm{PM}_{10}$ WSOC concentrations were also higher in winter than in summer. In contrast to the urban PU and KT sites, higher percentages of WSOC in TC were found at the HT site in both seasons. Average WSOC/EC ratios were $<1$ at the PU and KT sites, and $\sim 2.0$ to 2.5 at the HT site. These spatial variations suggested that a high WSOC fraction might be associated with aged aerosol. In addition, there were no notable differences for summer/winter distributions of carbon isotopic composition, indicating that motor vehicle sources were the main contributors of carbonaceous particles within the urban areas. Spatial distributions of $\delta^{13} \mathrm{C}$ in EC were uniform, reconfirming the dominant influence of motor vehicle 
source. However, lighter isotopic compositions in OC found at the HT site, compared with those at the urban sites, indicated the existence of biogenic sources at the regional-scale site. It is apparent that the use of carbon isotope composition in combination with $\mathrm{OC}$ and $\mathrm{EC}$ has considerable potential to allow for a more detailed assessment of source identification. These analyses may provide a feasible and cost effective technique for conducting source determinations and for quantitatively estimating relative contributions of different sources.

Acknowledgements. This project is supported by the Research Grants Council of Hong Kong (PolyU5038/01E, PolyU5145/03E) and the Natural Science Funding of China (NSFC 40205018).

Edited by: T. Röckmann

\section{References}

Ballentine, D. C., Macko, S. A., and Turekian, V. C.: Variability of stable carbon isotopic compositions in individual fatty acids from combustion of $\mathrm{C} 4$ and $\mathrm{C} 3$ plants: implications for biomass burning, Chem. Geol., 152, 151-161, 1998.

Cachier, H., Buat-Menard, P., Fontugne, M., and Rancher, J.: Source terms and source strengths of the carbonaceous aerosol in the Tropics., J. Atmos. Chem., 3, 469-489, 1985.

Cachier, H., Buat-Menard, P., Fontugne, M., and Chesselet, R.: Long-range transport of continentally-derived particulate carbon in the marine atmosphere: evidence from stable carbon isotopes studies, Tellus, 38B, 161-177, 1986.

Cachier, H., Bremond, M.-P., and Buat-Menard, P.: Carbonaceous aerosols from different tropical biomass burning sources, Nature, 340, 371-373, 1989.

Cao, J. J., Lee, S. C., Ho, K. F., Zhang, X. Y., Zou, S. C., Fung, K., Chow, J. C., and Watson, J. G.: Characteristics of Carbonaceous Aerosol in Pearl River Delta Region China during 2001 Winter Period, Atmos. Environ., 37, 1451-1460, 2003.

Chameides, W. L.: Bergin M. Soot Takes Center Stage, Science, 297, 2214-2215, 2002.

Chebbi, A. and Carlier, P.: Carboxylic acids in the troposphere, occurrence, sources, and sinks: A review, Atmos. Environ., 30, 4233-4250, 1996.

Cheng, Z. L., Lam, K. S., Chan, L. Y., Wang, T., and Cheng, K. K.: Chemical characteristics of aerosols at coastal station in Hong Kong. I. Seasonal variation of major ions halogens and mineral dusts between 1995 and 1996, Atmos. Environ., 34, 2771-2783, 2000.

Chesselet, R., Fontugne, M., Buat-Menard, P., Ezat, U., and Lambert, C. E.: The origin of particulate organic carbon in the marine atmosphere as indicated by its stable carbon isotopic composition, Geophys. Res. Lett., 8, 345-348, 1981.

Chow, J. C., Watson, J. G., Lowenthal, D. H., Solomon, P. A., Magliano, K. L., Ziman, S. D., and Richards, L. W.: PM 10 and $\mathrm{PM}_{2.5}$ compositions in California's San Joaquin valley, Aerosol Sci. Technol., 18, 105-128, 1993.

Cooke, W. F., Liousse, C., and Cachier, H.: Construction of a $1^{\circ} \times 1^{\circ}$ fossil fuel data set for carbonaceous aerosol and imple- mentation and radiative impact in the ECHAM4 model, J. Geophys. Res., 104(D18), 22 137-22 162, 1999.

Currie, L. A., Klouda, G. A., Benner Jr., B. A., Garrity, K., and Eglinton, T. I.: Isotopic and molecular fractionation in combustion three routes to molecular marker validation including direct molecular "dating” (GC/AMS), Atmos. Environ., 33, 27892806, 1999.

Frazer, L.: Seeing through soot, Environ. Health Perspect., 110, A471-A473, 2002.

Fung, K. K. and Wright, B.: Particulate Carbon Speciation by $\mathrm{MnO}_{2}$ Oxidation, Aerosol Sci. Technol., 12, 122-127, 1990.

Fung, K. K., Chow, J. C., and Watson, J. G.: Evaluation of OC/EC Speciation by Thermal Manganese Dioxide Oxidation and the IMPROVE Method, JAWMA, 52, 1333-1341, 2002.

Grosjean, D., Van Cauwenberghe, K., Schmid, J., Kelley, P., and Pitts, J. N.: Identification of $\mathrm{C}_{3}-\mathrm{C}_{10}$ aliphatic dicarboxylic acids in airborne particulate matter, Environ. Sci. Technol., 12, 313317, 1978.

Ho, K. F., Lee, S. C., Chan, C. K., Yu, J. C., Chow, J. C., and Yao, X. H.: Characterization of chemical species in $\mathrm{PM}_{2.5}$ and $\mathrm{PM}_{10}$ aerosols in Hong Kong, Atmos. Environ., 37, 31-39, 2003.

Ho, K. F., Lee, S. C., Guo, H., and Tsai, W. Y.: Seasonal and diurnal variations of volatile organic compounds (VOCs) in the atmosphere of Hong Kong, Sci. Total Environ., 322, 155-166, 2004.

Huang, L., Brook, J. R., Zhang, W., Li, S. M., Graham, L., Ernst, D., Chivulescu, A., and Lu, G.: Stable isotope measurements of carbon fractions (OC/EC) in airborne particulate: A new dimension for source characterization and apportionment. Atmos. Environ. 40, 2690-2705, 2006.

Kim, Y. P., Moon, K.-C., Shim, S.-G., Lee, J. H., Kim, J. Y., Fung, K., Camichael, G. R., Song, C. H., Kang, C. H., Kim, H.-K., and Lee, C. B.: Carbonaceous species in fine particles at the background sites in Korea between 1994 and 1999, Atmos. Environ., 34, 5053-5060, 2000.

Martinelli, L. A., Camargo, P. B., Lara, L. B. L. S., Victoria, R. L., and Artaxo, P.: Stable carbon and nitrogen isotopic composition of bulk aerosol particles in a C4 plant landscape of southeast Brazil, Atmos. Environ., 36, 2427-2432, 2002.

Menon, S., Hansen, J., Nazarenko, L., and Luo, Y. F.: Climate Effects of Black Carbon Aerosols in China and India, Science, 297, 2250-2253, 2002.

Reddy, C. M., Pearson, A., Xu, L., Mchichol, A. P., Benner, B. A., Wise, S. A., Klouda, G. A., Currie, L. A., and Eglinton, T. I.: Radiocarbon as a Tool To Apportion the Sources of Polycyclic Aromatic Hydrocarbons and Black Carbon in Environmental Samples, Environ. Sci. Technol., 36, 1774-1782, 2002.

Rogge, W. F., Mazurek, M. A., Hildemann, L. M., Cass, G. R., and Simoneit, B. R. T.: Quantification of urban organic aerosols at a molecular level: Identification, abundance and seasonal variation, Atmos. Environ., 27A, 1309-1330, 1993.

Rudolph, J., Czuba, E., Norman, A. L., Huang, L., and Ernst, D.: Stable carbon isotope composition of nonmethane hydrocarbons in emissions from transportation related sources and atmospheric observations in an urban atmosphere, Atmos. Environ., 36, 1173-1181, 2002.

Ruellan, S. and Cachier, H.: Characterisation of fresh particulate vehicular exhausts near a Paris high flow road, Atmos. Environ., 35, 453-468, 2000.

Salma, I., Maenhaut, W., Zemplen-Papp, E., and Zaray, G.: Com- 
prehensive characterisation of atmospheric aerosols in Budapest Hungary: physicochemical properties of inorganic species, Atmos. Environ., 35, 4367-4378, 2001.

Saxena, P. and Hildemann, L. M.: Water-soluble organics in atmospheric particles: a critical review of the literature and application of thermodynamics to identify candidate compounds, J. Atmos. Chem., 24, 57-109, 1996.

Sequeira, R. and Lai, K.-H.: Small-scale spatial variability in the representative ionic composition of rainwater within urban Hong Kong, Atmos. Environ., 32, 133-144, 1998.

Shulman, M. L., Jacobson, M. C., Charlson, R. J., Synovec, R. E., and Young, T. E.: Dissolution behavior and surface tension effects of organic compounds in nucleating cloud droplets, Geophys. Res. Lett., 23, 277-280, 1996.

Streets, D. G., Carmichael, G. R., Amann, M., and Arndt, R. L.: Energy consumption and acid deposition in Northeast Asia, Ambio, 28, 135-143, 1999.

Szidat, S., Jenk, T. M., Gaggeler, H. W., Synal, H. A., Fisseha, R., Baltensperger, U., Kalberer, M., Samburova, V., Wacker, L., Saurer, M., Schwikowski, M., and Hajdas, I.: Source apportionment of aerosols by ${ }^{14} \mathrm{C}$ measurements in different carbonaceous particle fractions, Radiocarbon, 46(1), 475-484, 2004.

Temesi, D., Molnar, A., Meszaros, E., and Feczko, T.: Seasonal and diurnal variation in the size distribution of fine carbonaceous particles over rural Hungary, Atmos. Environ., 37, 139-146, 2003.
Turekian, V. C., Macko, S., Ballentine, D., Swap, R. J., and Garstang, M.: Causes of bulk carbon and nitrogen isotopic fractionations in the products of vegetation burns: laboratory studies, Chem. Geol., 152, 181-192, 1998.

Turpin, B. J. and Huntzicker, J. J.: Identification of secondary organic aerosol episodes and quantitation of primary and secondary organic aerosol concentrations during SCAQS, Atmos. Environ., 29, 3257-3544, 1995.

Watson, J. G., Chow, J. C., and Chen, L.-W. A.: Summary of methods and comparison studies for organic and elemental carbon: Implications for visibility and global warming, in: Proceedings, Regional and Global Perspectives on Haze: Causes, Consequences and Controversies Visibility Specialty Conference, edited by: Pitchford, M. and Poirot, R., Air and Waste Management Association, Pittsburgh, PA, 55-1-55-38, 2004.

Yang, H., Li, Q. F., and Yu, J. Z.: Comparison of two methods for the determination of water-soluble organic carbon in atmospheric particles, Atmos. Environ., 37, 865-870, 2003.

Yao, X. H., Fang, M., and Chan, C. K.: Size distributions and formation of dicarboxylic acids in atmospheric particles, Atmos. Environ., 36, 2099-2107, 2002.

Yao, X. H., Fang, M., Chan, C. K., Ho, K. F., and Lee, S. C.: Characterization of dicarboxylic acids in $\mathrm{PM}_{2.5}$ in Hong Kong, Atmos. Environ., 38, 963-970, 2004. 